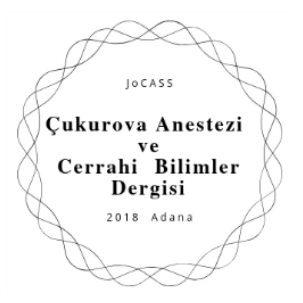

\title{
FEAR, PHOBIA, ANXIETY AND DEPRESSION SYMPTOM LEVELS IN RHEUMATOID ARTHRITIS AND ANKYLOSING SPONDYLITIS PATIENTS DURING THE COVID-19 OUTBREAK IN TURKEY COVID-19 SALGINI SIRASINDA ROMATOID ARTRIT VE ANKILOZAN SPONDILIT HASTALARINDA
KORKU, FOBI, ANKSIYETE VE DEPRESYON SEMPTOM DÜZEYLERI
}

Suade Ozlem Badak ${ }^{1}$, (D) Esra Gulturk², (D) Emine Duygu Ersozlu ${ }^{1}$

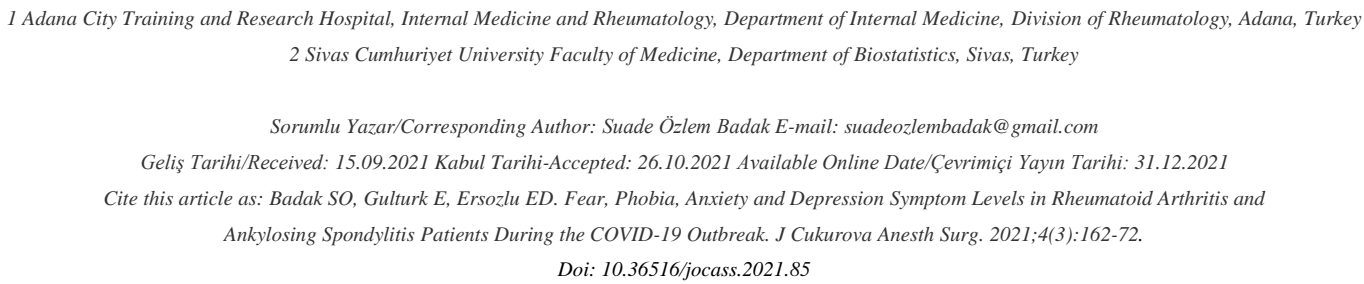

\section{Abstract}

Aim: This study aims to investigate the psychological symptom levels associated with COVID-19 in rheumatoid arthritis and ankylosing spondylitis in remission.

Methods: A cross-sectional study was conducted between October 1 and December 31, 2020. Two hundred forty-eight patients meeting the criteria were included in the study. Coronavirus-induced fear, phobia, depression, and anxiety symptoms were evaluated. For this purpose, the Fear of COVID-19 Scale (FCV-19S), Covid-19 Phobia Scale (C19P-S), Beck Depression Inventory (BDI), Beck Anxiety Inventory (BAI) were used.

Results: Most of the participants had high levels of fear, anxiety, and depressive symptoms. C19P-S, FCV-19S, BDI, and BAl scores showed significant simultaneous correlations $(p<0.05$, each other). The scores of the patients using Biological DMARDs (Disease-modifying antirheumatic drugs) were significantly higher $(p<0.001)$. The scores of the healthcare workers were significantly higher $(p<0.001)$. Among those who interrupted their routine outpatient visits, the rate of those who did not catch COVID-19 was higher $(74.7 \%)(p<0.01)$. Common risk factors for symptoms of fear, anxiety, and depression associated with COVID-19 were concomitant illness and being a healthcare worker.

Conclusions: By transferring current recommendations on COVID-19 and chronic diseases to more patients, exaggerated fear caused by both their diseases and the drugs used can be prevented, and the continuation of the treatment can be contributed. In addition, if necessary, consulting the relevant departments for supportive and medical treatments may contribute to the continuation of the treatment and the prevention of the activation of the disease.

Keywords: COVID-19, Covid-19 Phobia Scale, Fear of COVID-19 Scale, depression, anxiety, rheumatology

\section{Öz}

Amaç: Bu çalışma, romatoid artrit ve remisyondaki ankilozan spondilitte COVID-19 ile ilişkili psikolojik semptom düzeylerini araştırmayı amaçlamaktadır.

Yöntemler: 1 Ekim ile 31 Aralık 2020 tarihleri arasında kesitsel bir çalışma yapılmıştır. Kriterleri karşılayan iki yüz kırk sekiz hasta çalışmaya dahil edildi. Koronavirüs kaynaklı korku, fobi, depresyon ve anksiyete belirtileri değerlendirildi. Bu amaçla COVID-19 Korku Ölçeği (FCV-19S), Covid-19 Fobi Ölçeği(C19p-S), Beck Depresyon Ölçeği (BDI), Beck Anksiyete Ölçeği (BAI) kullanildı.

Bulgular: Katılımcıların çoğunda yüksek düzeyde korku, kaygı ve depresif belirtiler vardı. COVID-19 Korku Ölçeği, Covid-19 Fobi Ölçeği, Beck Depresyon Ölçeği ve Beck Anksiyete Ölçeği puanları anlamlı eş zamanlı korelasyonlar gösterdi $(p<0.05$, her biri). Biyolojik DMARD(Diseasemodifying antirheumatic drugs) kullanan hastaların, sağlık çalışanlarının puanları anlamlı olarak daha yüksekti $(p<0,001$, her biri). Rutin poliklinik ziyaretlerine ara verenler arasında, COVID-19'a yakalanmayanların oranı $(\% 74,7)$ daha yüksekti $(p<0.01)$. COVID-19 ile ilişkili korku, endişe ve depresyon semptomları için ortak risk faktörleri, eşlik eden hastalık ve sağlık çalışanı olmaktı.

Sonuç: COVID-19 ve kronik hastalıklarla ilgili güncel öneriler daha fazla hastaya aktarllarak hem hastalıklarından hem de kullanılan ilaçlardan kaynaklanan abartılı korkunun önüne geçilebilir ve tedavinin devamına katkı sağlanabilir. Ayrıca gerekirse destekleyici ve medikal tedaviler için ilgiili bölümlere danışıması tedavinin devamına ve hastalı̆ı̆ aktivasyonunun önlenmesine katkı sağlayabilir.

Anahtar Kelimeler: COVID-19, Covid-19 Fobi Ölçeği, COVID-19 Korku Ölçeği, depresyon, anksiyete, romatoloji 


\section{Introduction}

In December 2019, a viral disease called New Type Coronavirus Disease (COVID19) appeared in Wuhan. It has been observed that COVID-19, which occurs in a wide clinical spectrum, can progress more seriously in those with advanced age, immune system dysfunction, and chronic disease. In a study conducted with 1099 patients, it was found that $23.7 \%$ of the patients had at least one concomitant chronic disease ${ }^{1}$. Individuals with chronic diseases were also found to have a higher risk of developing serious adverse outcomes.

In this process, it was thought that individuals with rheumatological diseases might be worried about their chronic autoimmune diseases and immunosuppressants. In addition, it was emphasized that Rheumatoid arthritis (RA) and Ankylosing Spondylitis (AS), which additional diseases such as cardiovascular diseases are common, may adversely affect the course of COVID-19. In a study, it was stated that $54 \%$ of 112 patients with rheumatological diseases thought they were at "much higher risk" for COVID-19 due to their current disease and the drugs they used $^{2}$. It was stated that various emotional states such as extreme fear and disproportionate anxiety might manifest themselves as coronaphobia and that fear levels associated with COVID-19 are associated with the severity of depressive and anxiety symptoms ${ }^{3,4}$. It may be considered that these extreme psychological responses that develop with the concern of COVID-19 may cause people with chronic diseases, which require regular follow-up, to discontinue their medication and not refer to health centers where the risk of encountering the virus is high.

Since March 2020, when the first case was seen in our country, many measures have been taken to prevent the spread of the virus. However, until the writing stage of our article, our rheumatology outpatient clinic service was never interrupted.
Patients could reach our rheumatology outpatient clinic as easily as before the pandemic, and chronically ill individuals could obtain their medicines from the pharmacy without a prescription. This study aimed to determine the level of fear, phobia, anxiety, and depression symptoms caused by COVID-19 in patients with rheumatoid arthritis and ankylosing spondylitis in remission and investigated the effect on these variables of potentially affecting factors. It was aimed to emphasize the importance of regular follow-up and treatment in chronic diseases and the importance of evaluating psychological symptoms.

\section{Materials and Methods}

This is a cross-sectional study. Patients with $\mathrm{RA}$ and AS in remission who applied to Adana City Training and Research Hospital's rheumatology outpatient clinic between the beginning of October 2020 and the end of December 2020 were included in the study.

RA and AS patients over 18 years of age with disease activity in remission were included in the study. All patients were informed about the study procedure, and their written consents were obtained. Our patients were diagnosed with RA and AS, non-radiographic axial spondyloarthritis according to the 2010 ACR / EULAR criteria $^{5}$ and $\mathrm{ASAS}^{6}$ classification criteria, respectively. Our remission criteria; DAS $28^{7}$ for RA was $<2.6$, for AS ASDAS $<2.1^{8}$.

There were four patients diagnosed with dementia, 19 patients with psychiatric illness (such as major depression, anxiety disorders, psychotic disorders, bipolar disorder), and/or using psychiatric drugs. These diagnoses were confirmed by examining medical records. Three patients could not speak Turkish, and twenty-four patients refused to participate in the study. There were missing data in the assessment scales of 12 patients. Thus, a total of 248 
patients were included in the study (Figure $1)$.

All patients were informed about the study procedure, and their written consent were obtained. The patients' demographic characteristics were obtained directly from the patients. The drugs and comorbidities used were obtained from the patients' files. It was asked whether the participants or his/her relative had a previous COVID-19 diagnosis (SARS CoV-2 PCR positive), whether they were actively working outside (the obligation to go outside for work) and whether they disrupted their routine controls and treatments with the concern of Covid-19.

The study was approved by the Turkey's Health Ministry (Approval number: 202012-09T09_41_49) and Çukurova University Clinical Research Ethics Committee (Approval number: 104-26).

\section{- Instruments}

Coronavirus 19 Phobia (CP19-S) Scale ${ }^{4}$, Fear of COVID-19 Scale (FCV-19S) ${ }^{9-10}$, Beck Anxiety Inventory (BAI) ${ }^{11-12}$, and Beck Depression Inventory (BDI) ${ }^{13-14}$ were used to evaluate psychiatric symptoms.

The C19P-S is a five-point Likert-type scale to assess the levels of COVID-19 phobia. C19P-S is a self-reported questionnaire consisting of 20 items and four subscales, i.e., psychological, psychosomatic, economic, and social. All items are rated on a 5-point scale from "strongly disagree (1)" to "strongly agree (5)". The total score ranges from 20 to 100 points, and the higher the score, the higher the level of coronaphobia.

Participants' fear of contracting COVID-19 infection was evaluated with the FCV-19S. The FCV19S is a 5-point Likert scale consisting of seven items. Possible scores range from 7 to 35, with higher scores indicative of greater coronavirus fear. Potential responses to each item are made on a five-point Likert scale, ranging from 1 (Strongly disagree) to 5 (Strongly agree).
The cut-off score equal to or above 19 indicated high levels of COVID-19-related fear ${ }^{15}$.

BAI is used to determine the frequency of anxiety symptoms experienced by individuals. BAI is a Likert-type selfassessment tool consisting of 21 items, of which each is rated from 0 to 3 points. The anxiety level is measured according to the total score on this scale $(0-7$ points $=$ minimum, 8-15 points $=$ mild anxiety, 1625 points $=$ moderate anxiety, $26-63$ points = severe anxiety).

BDI is used to determine the risk of depression and to measure the level and severity of depressive symptoms, and measure the physical, emotional, cognitive, and motivational symptoms of depression. Consisting of 21 items, the scale is answered as 4 Likert between 0-3.

\section{- Statistical Analysis}

All statistical analyses were performed by the utilization of the IBM SPSS Statistics Version 22.0 statistical software package. Categorical variables were expressed as numbers and percentages. Continuous variables, on the other hand, were defined as the median and interquartile range (IQR), according to the structure of the statistical expression. The normality distribution was checked with Kolmogorov Smirnov. The comparison of the continuous variables of the two groups was made by the utilization of the Mann-Whitney U test, and the Kruskal Wallis test was used to compare more than two groups of continuous variables. Spearman correlation tests were used to evaluate relation grouped as individuals with anxiety, depression, and fear based on BAI, BDI, FCV19S cut-off scores, and binary logistic regression was used to identify associated with anxiety, depression, and fear. The significance level for all statistical tests was designated as $\mathrm{p}<$ 0.05 . 
310 Rheumatoid arthritis and Ankylosing spondylitis patients with disease activity in remission admitted between October 2020 and the end of December 2020

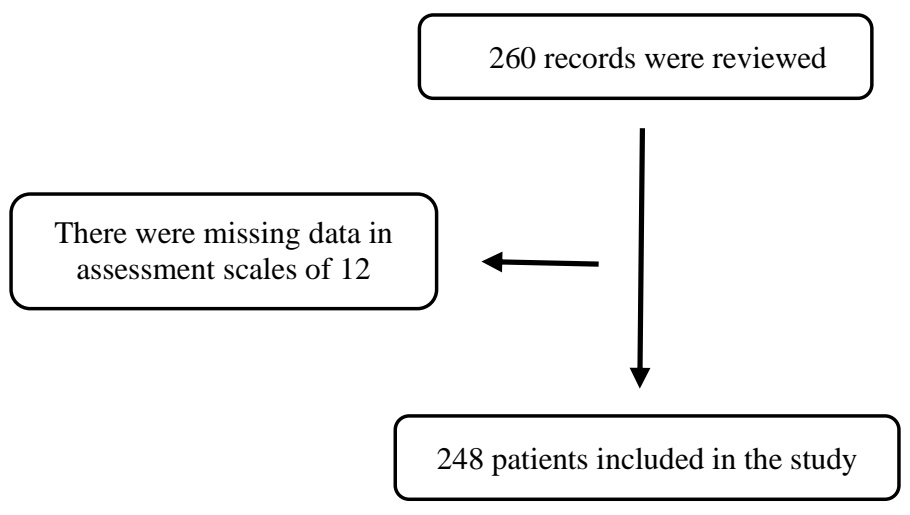

19 patients were with a known psychiatric diagnosis and/or using psychiatric medication

4 patients had a diagnosis of dementia* 3 patients could not speak Turkish 24 patients refused to participate in the study

Figure 1. Flowchart of excluded cases

*These diagnoses were confirmed by examining medical records.

\section{Results}

Patient characteristics and BAI, BDI, C19P$\mathrm{S}, \mathrm{FCV}-19 \mathrm{~S}$ scores of the participants are shown in Table 1.

The C19P-S had significant correlations with BAI $(\mathrm{r}=0.87, \mathrm{P}<0.05)$, BDI $(\mathrm{r}=0.83$ $\mathrm{P}<0.05)$, FCV-19S $(\mathrm{r}=0.91, \mathrm{P}<0.05)$. The FCV-19S score correlated with the BAI ( $\mathrm{r}$ $=0.87, \mathrm{P}<0.001)$, and BDI $(\mathrm{r}=0.87, \mathrm{P}<$ 0.05). BDI and BAI scores correlated with each other $(r=0.93, \mathrm{P}<0.05)$.

No relationship was found between gender, diagnosis, educational status, and BAI, BDI, FCV-19S, and CP19-S ( $p>0.05$ ). It was observed that BAI, BDI, FCV19S, CP19-S scores increased significantly with increasing age ( $\mathrm{p}<0.001)$.

Those who did not have COVID-19, married people, those who went out to work, having an additional comorbid disease, and smokers reported significantly higher levels of COVID-19- related fear $(p<0.001)$ and phobia $(p<0.001)$, more severe depressive $(p<0.001)$, and anxiety symptoms ( $\mathrm{p}<0.001)$.

When the BAI, BDI, FCV-19S, and CP19$S$ scores of those who received nonbiological DMARDs (Diseasemodifying antirheumatic drugs) and biological DMARDs were compared, a statistically significant difference was found in terms of drug groups. The scores of the patients using Biological DMARDs were significantly higher ( $\mathrm{p}<0.001)$. When the BAI, BDI, FCV-19S, and CP19-S scores were compared, a statistically significant difference was found between healthcare professionals and other occupational groups. The scores of the healthcare workers were significantly higher ( $p<0.001)$. The BAI, BDI, FCV19S, and CP19-S scores were significantly higher in those whose family members did not contract COVID-19 ( $p<0.001$ ). 49.6\% 
of the patients postponed their planned outpatient clinic visits due to COVID-19 concerns. BAI, BDI, FCV19S, CP19-S scores of those who interrupted treatment and postponed scheduled outpatient clinic controls were significantly higher ( $p$ $<0.001$ ) (Table 2).

Among those who interrupted their routine outpatient visits, the rate of those who did not catch COVID-19 was higher (74.7\%) (p $<0.01)$.

According to the results of binary logistic regression analysis (table 3 ).

Risk factors for fear of COVID-19 were being a healthcare worker, having additional illnesses, and not having COVID-19. Risk factors for anxiety symptoms were being a healthcare worker, having an additional comorbid disease, while risk factors for depression symptoms were an active worker outside, being a healthcare worker, not having COVID-19, and having additional illnesses.

\section{Discussion}

This study is the first face-to-face study to examine the symptoms and levels of fear, phobia, anxiety, and depression caused by COVID-19 in patients with RA and AS in remission. As a result of our study, we found that most participants had high fear, anxiety, and depressive symptoms. We identified the common risk factors for fear, anxiety, and depression symptoms associated with COVID-19 as comorbidity and being a healthcare worker.

Among the risk factors for severe disease, advanced age, comorbidity, smoking, use of immunosuppression, or immuneweakening medications were frequently highlighted $^{1}$. It has often been emphasized that older individuals, immunecompromised patients, and those with chronic diseases may experience more anxiety, depression, and anxiety due to COVID- $19^{16}$.

In a web-based study in the first month of the pandemic, the prevalence of anxiety, depression in patients with rheumatologic disease was found to be $20 \%, 43 \%$, respectively. Female gender, hospital work, low education level, having children, living in a crowded family, watching television or social media, contracting COVID-19, smoking, having a comorbid illness, and presence of a psychiatric illness have been reported to increase the odds ratio of psychiatric symptoms during the COVID19 outbreak $^{17}$.

Independent of COVID-19, the prevalence of anxiety in patients with RA and AS, which are chronic diseases, was reported as $20 \%$ and $18 \%$, respectively, which was closely related to disease activity ${ }^{18,19}$. In this respect, it was important that our patients were in remission in terms of disease activities.

Fear is a powerful emotion that affects individuals' physical reactions, cognitive skills, and moods. In their study with The FCV-19S, Bakioğlu ${ }^{20}$ found that females and those with chronic diseases had more fear of COVID-19. They also observed that the fear of COVID-19 increased the level of depression, anxiety, and stress intolerance. For the diagnosis of phobia, the individual's disproportionate fear and anxiety response are sufficient. Phobias can trigger other anxiety, major depression, and suicidal tendencies. In addition to the fear of contacting COVID-19, disruption of people's routines also contributes to anxiety and phobic reactions. According to BDI and BAI, $48.4 \%$ of our patients had moderateto-severe depressive symptoms, and $41.9 \%$ had moderate-severe anxiety symptoms.

A significant ratio of the participants reported high levels of COVID- 19 fear $(48.8 \%)$ and phobia (47.4\%).

Ahorsu $^{9}$ also noted that the COVID-19 pandemic caused fear, anxiety, depression, anxiety in humans and that levels of fear associated with COVID-19 positively correlated with the severity of depressive and anxiety symptoms.

According to our results, the significant correlation between BAI, BDI, FCV19S, CP19-S supported this. 
Table 1. Patient characteristics and applying to outpatient clinic control and BAI, BDI, C19PS, FCV-19S scores of the participants

\begin{tabular}{|c|c|c|}
\hline Female, n (\%) & & $128(51.6)$ \\
\hline Age. (years), median, (IQR) & & $44(21)$ \\
\hline Disease duration (months), median, (IQR) & & $72(156)$ \\
\hline & Rheumatoid arthritis & $124(50)$ \\
\hline Diagnosis, n (\%) & Ankylosing spondylitis & $124(50)$ \\
\hline Marital status n (\%) & Married & $163(65.7)$ \\
\hline Minartal status, in ( & Single & $85(34.3)$ \\
\hline & Primary school & $37(14.9)$ \\
\hline Educational status, n (\%) & Middle school & $72(29)$ \\
\hline & High school & $77(31)$ \\
\hline & Higher & $62(25)$ \\
\hline Smoking, n (\%) & & $52(33.1)$ \\
\hline & Hypertension & $30(21.1)$ \\
\hline & Diabetes & $15(6)$ \\
\hline & Chronic pulmonary Disease & $28(11.3)$ \\
\hline & Chronic Kidney Disease & $6(2.4)$ \\
\hline Comorbid disease, $\mathrm{n}(\%)$ & Chronic Liver Disease & $2(0.8)$ \\
\hline & Coronary Artery Disease & $19(7.7)$ \\
\hline & Other & $6(2.4)$ \\
\hline & NSAID & $33(13.3)$ \\
\hline Medication, n (\%) & cDMARDs & $123(49.6)$ \\
\hline & bDMARD & $92(37.1)$ \\
\hline Before having COVID-19, n (\%) & & 99(39.9) \\
\hline Family relative diagnosed with COVID-19, n (\%) & & $110(44.2)$ \\
\hline Have to go out for work, $n(\%)$ & & $113(45.6)$ \\
\hline $\begin{array}{l}\text { İnterrupting outpatient clinic controls, } n(\%) \text {, } \\
\text { (with own request) }\end{array}$ & & $123(49.6)$ \\
\hline Skipped medication, $\mathbf{n}(\%)$ & & $63(25.4)$ \\
\hline BAI score, median (IQR) & & $14(35)$ \\
\hline & No anxiety & $3(1.2)$ \\
\hline BAI score, interpretation, n (\%) & Mild & $125(50.4)$ \\
\hline & Moderate & $39(15.7)$ \\
\hline & Severe & $81(32.7)$ \\
\hline BDI score, median (IQR) & & $9(29)$ \\
\hline & No depression & $136(54.8)$ \\
\hline & Mild & $8(3.2)$ \\
\hline BDI score, interpretation, n (\%) & Moderate & $32(12.9)$ \\
\hline & Severe & $72(29)$ \\
\hline & Total & $25(63)$ \\
\hline & Psychological & $9(21)$ \\
\hline C19P-S score, median (IQR) & Psycho-somatic & $6(15)$ \\
\hline & Social & $7.5(18)$ \\
\hline & Economic & $5(8)$ \\
\hline FCV-19S score, median (IQR) & & $11.5(24)$ \\
\hline FCV-19S score, interpretation, n (\%) & Normal fear & $127(51.2)$ \\
\hline
\end{tabular}

DMARD; disease-modifying antirheumatic drug, NSAID; nonsteroidal anti-inflammatory drugs,

BAI: Beck Anxiety Inventory, BDI: Beck Depression Inventory, FCV-19S: Fear of COVID-19 Scale,

CP19-S: Coronavirus 19 Phobia Scale, IQR: Interquartile Range 
Table 2. Comparison of the anxiety, depression, fear, and phobia symptom scores of the participants

\begin{tabular}{|c|c|c|c|c|c|c|c|c|c|}
\hline & & \multicolumn{2}{|c|}{ BAI } & \multicolumn{2}{|c|}{ BDI } & \multicolumn{2}{|c|}{ FCV19-S } & \multicolumn{2}{|c|}{ CP19-S } \\
\hline Variables & & $\begin{array}{l}\text { Median } \\
(\mathrm{IQR})\end{array}$ & p-value & $\begin{array}{c}\text { Median } \\
(\mathrm{IQR})\end{array}$ & p-value & $\begin{array}{l}\text { Median } \\
(\mathrm{IQR})\end{array}$ & p-value & $\begin{array}{c}\text { Median } \\
\text { (IQR) }\end{array}$ & $\mathrm{p}$-value \\
\hline Diagnosis & $\begin{array}{l}\text { Ankylosing } \\
\text { spondylitis } \\
\text { Rheumatoid } \\
\text { arthritis }\end{array}$ & $\begin{array}{c}14(37) \\
12.5(33)\end{array}$ & 0.894 & $\begin{array}{l}9(29) \\
9(27)\end{array}$ & 0.939 & $\begin{array}{c}11(25) \\
11.50(24)\end{array}$ & 0.853 & $\begin{array}{c}24(63) \\
26.5(62)\end{array}$ & 0.969 \\
\hline Gender & $\begin{array}{l}\text { Male } \\
\text { Female }\end{array}$ & $\begin{array}{c}19.5(36) \\
9(35) \\
\end{array}$ & 0.640 & $\begin{array}{c}10.5(28) \\
7(29) \\
\end{array}$ & 0.851 & $\begin{array}{c}20.5(24) \\
10(24) \\
\end{array}$ & 0.443 & $\begin{array}{l}57(63) \\
24(61)\end{array}$ & 0.243 \\
\hline Age & - & - & 0.0001 & - & 0.0001 & - & 0.0001 & - & 0.0001 \\
\hline $\begin{array}{l}\text { Disease } \\
\text { duration }\end{array}$ & - & - & 0.005 & - & 0.019 & - & 0.0001 & - & 0.0001 \\
\hline Marital status & $\begin{array}{l}\text { Single } \\
\text { Married } \\
\end{array}$ & $\begin{array}{c}5(17) \\
31(34) \\
\end{array}$ & 0.0001 & $\begin{array}{c}3(8) \\
20(30)\end{array}$ & 0.0001 & $\begin{array}{c}8(13) \\
40(25)\end{array}$ & 0.0001 & $\begin{array}{l}21(11) \\
79(63)\end{array}$ & 0.0001 \\
\hline $\begin{array}{l}\text { Educational } \\
\text { status }\end{array}$ & $\begin{array}{l}\text { Primary } \\
\text { school } \\
\text { Middle } \\
\text { school } \\
\text { High school } \\
\text { Higher }\end{array}$ & $\begin{array}{l}11(34) \\
16(37) \\
12(35) \\
\end{array}$ & 0.559 & $\begin{array}{c}9(28) \\
10(33) \\
6(28) \\
\end{array}$ & 0.299 & $\begin{array}{l}10(24) \\
20(28) \\
10(28)\end{array}$ & 0.491 & $\begin{array}{c}25(60) \\
24.5(61) \\
75(63) \\
24(64)\end{array}$ & 0.691 \\
\hline Smoking & $\begin{array}{l}\text { Yes } \\
\text { No }\end{array}$ & $\begin{array}{c}34.5(36) \\
8(33)\end{array}$ & 0.0001 & $\begin{array}{c}21(31) \\
5(26)\end{array}$ & 0.004 & $\begin{array}{c}31.5(24) \\
9(24) \\
\end{array}$ & 0.0001 & $\begin{array}{c}81.5(64) \\
23(60) \\
\end{array}$ & 0.0001 \\
\hline $\begin{array}{l}\text { Comorbid } \\
\text { disease }\end{array}$ & $\begin{array}{l}\text { Yes } \\
\text { No }\end{array}$ & $\begin{array}{c}39(12) \\
5(8)\end{array}$ & 0.0001 & $\begin{array}{c}30(19) \\
3(6) \\
\end{array}$ & 0.0001 & $\begin{array}{l}32(3) \\
8(3) \\
\end{array}$ & 0.0001 & $\begin{array}{l}83(9) \\
21(4) \\
\end{array}$ & 0.0001 \\
\hline $\begin{array}{l}\text { Have to go out } \\
\text { for work }\end{array}$ & $\begin{array}{l}\text { Yes } \\
\text { No }\end{array}$ & $\begin{array}{c}32(36) \\
7(29)\end{array}$ & 0.0001 & $\begin{array}{l}21(31) \\
4.5(20)\end{array}$ & 0.0001 & $\begin{array}{c}30(24) \\
8(24)\end{array}$ & 0.0001 & $\begin{array}{c}81(63) \\
(22)\end{array}$ & 0.0001 \\
\hline Occupation & $\begin{array}{l}\text { Not } \\
\text { employed } \\
\text { Healthcare- } \\
\text { related job } \\
\text { Other }^{\text {s }}\end{array}$ & $\begin{array}{c}9(34) \\
40.5(18) \\
8(34)\end{array}$ & $0.0001^{\mathrm{b}}$ & $\begin{array}{l}7.5(26) \\
32(22) \\
5(26)\end{array}$ & $0.0001^{\mathrm{b}}$ & $\begin{array}{l}33(2) \\
9(25)\end{array}$ & $0.0001^{\mathrm{b}}$ & $\begin{array}{l}23(60) \\
85(8) \\
23(61)\end{array}$ & $0.0001^{b}$ \\
\hline $\begin{array}{l}\text { Before have } \\
\text { COVID-19 }\end{array}$ & $\begin{array}{l}\text { Yes } \\
\text { No }\end{array}$ & $\begin{array}{c}6(11) \\
33(35)\end{array}$ & 0.0001 & $\begin{array}{c}3(8) \\
22.5(30) \\
\end{array}$ & 0.0001 & $\begin{array}{c}8(5) \\
31(25) \\
\end{array}$ & 0.0001 & $\begin{array}{c}(22) \\
80.5(64) \\
\end{array}$ & 0.0001 \\
\hline $\begin{array}{l}\text { Family } \\
\text { relative } \\
\text { diagnosed } \\
\text { with COVID- } \\
19\end{array}$ & $\begin{array}{l}\text { Yes } \\
\text { No }\end{array}$ & $8(33)$ & 0.045 & $\begin{array}{l}4.5(26) \\
20(30)\end{array}$ & 0.003 & $30(24)$ & 0.044 & $23(61)$ & 0.042 \\
\hline $\begin{array}{l}\text { İnterrupting } \\
\text { outpatient } \\
\text { clinic } \\
\text { controls. }\end{array}$ & $\begin{array}{l}\text { Yes } \\
\text { No }\end{array}$ & $\begin{array}{l}39(13) \\
5(4)\end{array}$ & 0.0001 & $30(19)$ & 0.0001 & $32(3)$ & 0.0001 & $83(8)$ & 0.0001 \\
\hline $\begin{array}{l}\text { Skipped } \\
\text { medication }\end{array}$ & $\begin{array}{l}\text { Yes } \\
\text { No } \\
\end{array}$ & $\begin{array}{l}28(32) \\
9.5(35) \\
\end{array}$ & 0.019 & $\begin{array}{c}18(35) \\
6(28) \\
\end{array}$ & 0.039 & $\begin{array}{c}29(24) \\
9(25) \\
\end{array}$ & 0.009 & $\begin{array}{l}77(62) \\
23(62) \\
\end{array}$ & 0.012 \\
\hline Drugs & $\begin{array}{l}\text { NSAID } \\
\text { Non- } \\
\text { biological } \\
\text { DMARDs } \\
\text { Biological } \\
\text { DMARDs }\end{array}$ & $\begin{array}{l}4(6) \\
8(33) \\
36(33)\end{array}$ & $0.0001^{\mathrm{f}}$ & $\begin{array}{l}1(5) \\
6(23) \\
26(34)\end{array}$ & $0.0001^{\mathrm{f}}$ & $\begin{array}{l}7(3) \\
9(24) \\
31(24)\end{array}$ & $0.0001^{\mathrm{f}}$ & $\begin{array}{l}20(3) \\
24(60) \\
82(63)\end{array}$ & $0.0001^{\mathrm{f}}$ \\
\hline
\end{tabular}

BAI; Beck Anxiety Inventory, BDI: Beck Depression Inventory, FCV-19S; Fear of COVID-19 Scale, CP19-S; Coronavirus 19 Phobia, DMARD; disease-modifying antirheumatic drug, NSAID; nonsteroidal anti-inflammatory drugs

b,f Denotes statistically significant pairs 
Table 3. Effect of variables risk factors for COVID19 on anxiety, depression, and fear

\begin{tabular}{|c|c|c|c|}
\hline & & OR $(95 \%$ CI $)$ & p-value \\
\hline \multirow{2}{*}{$\begin{array}{c}\text { Anxiety } \\
\text { (Anxiety or non-anxiety) }\end{array}$} & Health-care workers & $28.597(2.853-286.606)$ & 0.004 \\
\hline & Comorbid diseases,yes & $9.621(3.075-30.105)$ & 0.0001 \\
\hline \multirow{4}{*}{$\begin{array}{c}\text { Depression } \\
\text { (Depression or non-depression) }\end{array}$} & Need to go out for work & $11.336(1.441-89.166)$ & 0.021 \\
\hline & Health-care workers & $8.130(1359-48.618)$ & 0.022 \\
\hline & Diagnosed with COVID-19, no & $0.096(0.014-0.666)$ & 0.018 \\
\hline & Comorbid diseases, yes & $6.372(1955-20.765)$ & 0.002 \\
\hline \multirow{3}{*}{$\begin{array}{l}\text { COVID-19 fear } \\
\text { (Fear or non-fear) }\end{array}$} & Health-care workers & $73.169(3.044-1758.555)$ & 0.008 \\
\hline & Comorbid diseases,yes & $19.268(4615-80.442)$ & 0.0001 \\
\hline & Diagnosed with COVID-19,no & $0.76(0.007-0.838)$ & 0.035 \\
\hline
\end{tabular}

OR: odds ratio; CI: confidence interval

In individuals with chronic diseases, concern for COVID-19 may also cause disruption in routine outpatient clinic controls and continuity of treatment. Within nine months from March 2020, in which our study was conducted, $49.6 \%$ of our patients had delayed their scheduled controls, and $25 \%$ had stopped taking their medication or postponed their infusions. In an article where the experiences of post-pandemic rheumatology clinical practice were compiled from different regions, it was stated that many patients had discontinuation of their medication or inappropriate self-treatment, which caused disease exacerbations in some patients ${ }^{21}$. It was fortunate that our patients who took a break from their treatment had not exacerbated their illnesses yet.

In our country, in web-based surveillance that lasted 20 days at the beginning of the pandemic, it was reported that $85.6 \%$ of those with rheumatological diseases did not want to come to the polyclinic visits, and $22.4 \%$ of them quit their medication ${ }^{17}$. An online survey of patients with inflammatory arthritis showed that anxiety for COVID-19 and self-isolation were more pronounced in females, those who received biological therapies, and those with comorbid diseases. They also observed that although drug compliance was high among patients, COVID-19 fear was the main cause of noncompliance. ${ }^{22}$.

Contrary to the concerns at the beginning of the pandemic, it has been shown that there is no increased risk of SARS-CoV-2 infection in patients receiving immunosuppressive DMARDs. Puttini ${ }^{23}$, on the other hand, retrospectively analyzed the records of 10,260 rheumatic patients who received bDMARDs or small molecules treatments, stating that such drugs do not pose a risk factor for COVID19. It has been shown that the disease is activated by reducing or discontinuing biological drugs ${ }^{24}$.

International and national rheumatology associations have published their guidelines on managing rheumatological diseases during the pandemic and are constantly updated. In patients with stable rheumatic disease but without suspected or diagnosed COVID-19, it was stated that hydroxychloroquine, sulfasalazine, methotrexate, leflunomide, immune-suppressants, biologics, and NSAIDs could be continued $^{25}$. Nevertheless, we found that COVID-19 induced fear, phobia, anxiety, and depression scores were significantly more pronounced in our patients who ceased their treatment $(\mathrm{p}<0.01)$.

One of the verdicts taken by our government regarding the pandemic was that chronic patients could obtain their medications from the pharmacy without a prescription. On the other hand, it was observed that $25 \%$ of our patients, most of whom were using bDMARDs, interrupted their treatment. This can be interpreted as they think that the risk of infection increases due to the drugs they use. According to our 
results, the significantly higher BAI, BDI, FCV19S, CP19-S scores of patients on bDMARDs treatment also supports this. If the patients stop taking their medications and make adjustments to their own treatment, it may disrupt the control of the rheumatological disease. The underlying inflammation or disease activity has been blamed as a risk factor for infection, which may be further increased by the use of glucocorticoids as salvage therapy ${ }^{25}$. On the other hand, aggravated disease can cause an increase in the levels of anxiety and depression symptoms, making the situation worse.

In our patients, BAI, BDI, FCV19S, CP19$\mathrm{S}$ scores significantly with increased age ( $\mathrm{p}$ $<0.001$ ). It has been previously shown that older age is associated with higher COVIDinduced anxiety and depressive symptoms $^{26}$.

There are different results in the literature regarding the impact of gender and marital status on the mental health of COVID- 19. In this study, while there was no difference between males and females in terms of coronavirus fear, phobia, depression, and anxiety symptoms ( $p>0.05$ ), we found significantly higher scores in married individuals compared to single ones ( $p$ $<0.001)$.

Mertens $^{27}$ reported that intolerance to uncertainty about the process of the epidemic, health concerns for themselves and their beloved people are related to the fear of COVID-19. Similarly, finding higher scores in our married patients may suggest that it is due to the concern that family members also become ill. It can be said that active workers outside have a higher risk of contact with the virus due to reasons such as public transport and the working environment. BAI, BDI, FCV19$\mathrm{S}$, and C19P-S scores were also significantly higher in our patients who worked outside than those at home $(\mathrm{p}<0.01$, for each).

Many healthcare workers worldwide fell ill during the epidemic, and some of them, unfortunately, died. During the COVID-19 epidemic, it was indicated that the high risk of healthcare workers getting the virus and infecting family members, changing their routines might cause mental problems. Their high anxiety levels may be related to the active role they take during their pandemic period.

At the end of our study, it has been observed that being a healthcare worker and having additional comorbid diseases may be common risk factors for COVID-19related fear, anxiety, and depression symptoms; not having COVID-19 can be risk factors for symptoms of fear and anxiety and going outside to work could be risk factors for depression symptom.

Hospitals are thought to be risky places to encounter the virus. As a result of the esurvey conducted with patients with systemic sclerosis ( $\mathrm{SSc}$ ), it was seen that the majority of patients preferred teleconsultations to hospital visits due to fear of catching COVID-19 and the maintenance of medical care was disrupted ${ }^{28}$. Although our patients had easy access to the rheumatology outpatient clinic as in the prepandemic period and did not undergo teleconsultation, still $49.6 \%$ preferred to postpone their scheduled controls, and the BAI, BDI, FCV19S, CP19-S scores of the patients in this group were significantly higher.

In the literature, at the beginning of the pandemic, there are studies conducted online on people's acute COVID-19 responses. This study is the first face-toface study to see the symptoms of fear, phobia, anxiety, and depression caused by COVID-19 in patients with RA and AS in remission. In addition, FCV19S and CP19$S$ were used for the first time in this patient group. The levels of psychological symptoms caused by COVID-19 and the factors that may affect them were specified. The importance of regular follow-up and treatment in chronic diseases was emphasized.

This study has several limitations. Our limitations include the lack of a control group and the absence of anxiety and 
depression scales for our pre-pandemic patients, although we did not include those with a diagnosis of known psychiatric diseases in the study. This study was conducted on patients in remission who came to the outpatient clinic during the three-month period. There is a possibility of selection bias. İt's a monocentric crosssectional study. We consider that our results should not be generalized to all patients with inflammatory rheumatic diseases.

\section{Conclusions}

As a result of our study, In addition to the regular follow-up of chronic diseases, we think it will be important to identify psychological symptoms that may disrupt their routine.

To convey current recommendations on COVID-19 and chronic diseases to more patients and consulting the relevant departments for supportive and medical treatments when necessary can contribute to the continuation of the treatment and the prevention of the activation of the disease.

\footnotetext{
Author contributions

All authors contributed to the study conception and design. Material preparation, data collection, and analysis were performed by Suade Ozlem Badak, Emine Duygu Ersozlu. Statistical analysis was done by Esra Gulturk. Suade Ozlem Badak wrote the first draft of the manuscript and all authors commented on previous versions of the manuscript. All authors read and approved the final manuscript.
}

\section{Conflict of Interest}

The authors declare that they have no conflict of interest.

\section{Funding}

Authors declared no financial support.

\section{Ethical approval}

This study, in which patients participated on a voluntary basis, was conducted in accordance with all ethical procedures /standards and the Declaration of Helsinki.

The study was approved by the Turkey's Health Ministry (Approval number: 2020-12-09T09_41_49) and Çukurova University Clinical Research Ethics Committee (Approval number: 104-26).

\section{References}

1. Guan WJ, Ni ZY, Hu Y, et al. China Medical Treatment Expert Group for Covid-19. Clinical Characteristics of Coronavirus Disease 2019 in China. N Engl J Med. Apr 2020;30;382(18):1708-20. https://doi.org/10.1056/NEJMoa2002032.

2. Duculan R, Jannat-Khah D, Mehta B,et al. Variables Associated With Perceived Risk of Contracting SARS-CoV-2 Infection During the COVID-19 Pandemic Among Patients With Systemic Rheumatic Diseases. J Clin Rheumatol. Apr 2021; 1;27(3):120-6. https://doi.org/10.1097/RHU.000000000000168 $\underline{6 .}$

3. Asmundson, G. J., Taylor, S. Coronaphobia: Fear and the 2019-nCoV outbreak. Journal of Anxiety Disorders. 2020; 70, 102196. https://doi.org/10.1016/j.janxdis. 2020.102196

4. Arpaci, I., Karatas, K., \& Baloglu, M. The development and initial tests for the psychometric properties of the COVID-19 Phobia Scale (C19P-S). Personality and DEATH STUDIES 5 Individual Differences.2020; 164, 110108.

https://doi.org/10. 1016/j.paid.2020.110108

5. Aletaha D, Neogi T, Silman AJ, et al. Rheumatoid arthritis classification criteria: an American College of Rheumatology/European League Against Rheumatism collaborative initiative. Arthritis Rheum. Sep 2010;62(9):2569-81. https://doi.org/10.1002/art.27584.

6. Sieper J, Rudwaleit M, Baraliakos X, et al. The Assessment of SpondyloArthritis international Society (ASAS) handbook: a guide to assess spondyloarthritis. Ann Rheum Dis. Jun 2009;68 Suppl 2:ii1-44. https://doi.org/10.1136/ard.2008.104018.

7. Van der Heijde DM, van 't Hof M, van Riel PL, et al. Development of a disease activity score based on judgment in clinical practice by rheumatologists. J Rheumatol. Mar 1993;20(3):579-81.

8. Lukas C, Landewé R, Sieper J, et al. Assessment of SpondyloArthritis international Society. Development of an ASAS-endorsed disease activity score (ASDAS) in patients with ankylosing spondylitis. Ann Rheum Dis. Jan 2009;68(1):18-24. https://doi.org/10.1136/ard.2008.094870

9. Ahorsu DK, Lin CY, Imani V, et al. The Fear of COVID-19 Scale: Development and Initial Validation. Int $\mathbf{J}$ Ment Health Addict. Mar 2020;27:1-9.

https://doi.org/10.1007/s11469-020-00270-8.

10. Haktanir A, Seki T, Dilmaç B. Adaptation and evaluation of Turkish version of the fear of 
COVID-19 scale. Death Stud. May 2020; 29:1-9. https://doi.org/10.1080/07481187.2020.1773026

11. Steer RA, Beck AT. Beck Anxiety Inventory. In: Zalaquett CP, Wood RJ, editors. Evaluating Stress: A Book of Resource. Lanham: MD: Scarecrow Education.1997; pp. 23-40.

12. Ulusoy M, Hisli N, Erkmen H. Turkish Version of the Beck Anxiety Inventory: Psychometric Properties. Journal of Cognitive Psychotherapy: An International Quarterly.1998;12.

13. Beck AT, Steer RA. Internal consistencies of the original and revised Beck Depression Inventory. J Clin Psychol. Nov 1984;40(6):1365-7. https://doi.org/10.1002/1097-4679(198411)

14. Hisli N. Validity and Reliability study of Beck Depression Inventory Turk J Psychol 1998;6:118-22.

15. Nikopoulou VA, Holeva V, Parlapani E, et al.Mental Health Screening for COVID-19: a Proposed Cut-off Score for the Greek Version of the Fear of COVID-19 Scale (FCV-19S). Int J Ment Health Addict. 2020 Nov 10:1-14. https://doi.org/10.1007/s11469-020-00414-w.

16. Pfefferbaum B, North CS. Mental Health and the Covid-19 Pandemic. N Engl J Med. Aug 6 2020;383(6):510-2.

https://doi.org/10.1056/NEJMp2008017.

17. Seyahi E, Poyraz BC, Sut N, et al. The psychological state and changes in the routine of the patients with rheumatic diseases during the coronavirus disease (COVID-19) outbreak in Turkey: a web-based cross-sectional survey. Rheumatol Int. Aug 2020;40(8):1229-38. https://doi.org/10.1007/s00296-020-04626-0.

18. Fiest KM, Hitchon CA, Bernstein $\mathrm{CN}$, et al. CIHR Team "Defining the Burden and Managing the Effects of Psychiatric Comorbidity in Chronic Immunoinflammatory Disease". Systematic Review and Meta-analysis of Interventions for Depression and Anxiety in Persons With Rheumatoid Arthritis. J Clin Rheumatol. Dec 2017;23(8):425-34. https://doi.org/10.1097/RHU.000000000000048 9.

19. Baysal O, Durmuş B, Ersoy Y, et al. Relationship between psychological status and disease activity and quality of life in ankylosing spondylitis. Rheumatol Int. Jun 2011;31(6):795-800. https://doi.org/10.1007/s00296-010-1381-X. Epub 2010 March 10.

20. Bakioğlu F, Korkmaz O, Ercan H. Fear of COVID-19 and Positivity: Mediating Role of Intolerance of Uncertainty, Depression, Anxiety, and Stress. Int J Ment Health Addict.2020;28:114.

https://doi.org/10.1007/s11469-020-00331-y.

21. Bonfá E, Gossec L, Isenberg DA (2021) How COVID-19 is changing rheumatology clinical practice. Nat Rev Rheumatol.2021;17(1):11-5. https://doi.org/10.1038/s41584-020-00527-5
22. Glintborg B, Jensen DV, Engel S, et al. Selfprotection strategies and health behaviour in patients with inflammatory rheumatic diseases during the COVID-19 pandemic: results and predictors in more than 12000 patients with inflammatory rheumatic diseases followed in the Danish DANBIO registry. RMD Open. Jan 2021;7(1):e001505.

https://doi.org/10.1136/rmdopen-2020-001505.

23. Sarzi-Puttini P, Marotto D, Caporali R, et al. Montecucco CM, Favalli EG, Franceschini F,et al.Prevalence of COVID infections in a population of rheumatic patients from Lombardy and Marche treated with biological drugs or small molecules: A multicentre retrospective study. J Autoimmun. Jan 2021;116:102545. https://doi.org/10.1016/j.jaut.2020.102545.

24. Smolen JS, Nash P, Durez P, et al. (2013) Maintenance, reduction, or withdrawal of etanercept after treatment with etanercept and methotrexate in patients with moderate rheumatoid arthritis (PRESERVE): a randomised controlled trial. Lancet. Mar 2013;381(9870):918-29. https://doi.org/10.1016/S0140-6736(12)61811$\mathrm{X}$

25. Mikuls TR, Johnson SR, Fraenkel L, et al. American College of Rheumatology Guidance for the Management of Rheumatic Disease in Adult Patients During the COVID-19 Pandemic: Version 3. Arthritis Rheumatol. Feb 2021;73(2):e1-e12. https://doi.org/10.1002/art.41596.

26. Peng S, Lai X, Du Y, et al. Prevalence and Associated Factors for Depressive Symptomatology in Chinese Adults During COVID-19 Epidemic. Front Psychol. Dec 23 2020; 11:616723.

https://doi.org/10.3389/fpsyg.2020.616723.

27. Mertens G, Gerritsen L, Duijndam S, et al. Fear of the coronavirus (COVID-19): Predictors in an online study conducted in March. J Anxiety Disord. 2020 Aug 2020;74:102258.

https://doi.org/10.1016/j.janxdis.2020.102258.

28. Gupta L, Kharbanda R, Agarwal V, et al. Patient Perspectives on the Effect of the SARS-CoV-2 Pandemic on Patients With Systemic Sclerosis: An International Patient Survey. J Clin Rheumatol. Jan 1, 2021;27(1):31-3. https://doi.org/10.1097/RHU.000000000000168 $\underline{1 .}$ 